\section{International Academic Institute for Science and Technology}

International Academic Journal of Business Management

Vol. 5, No. 3, 2018, pp. 176-187.

ISSN 2454-2768
International

Academic

Journal

of

Business Management

\title{
Employee Retention, Market Orientation, and Organizational Performance - An Empirical Study
}

\author{
Fatema Johara ${ }^{a}$, Sofri Bin Yahya ${ }^{b}$, Shehnaz Tehseen ${ }^{c}$ \\ ${ }^{a}$ Graduate School of Business, USM \& School of Business, BAIUST (Corresponding Author). \\ ${ }^{\mathrm{b}}$ Graduate School of Business, USM. \\ ${ }^{\mathrm{c}}$ Sunway University Business School, Sunway University.
}

\begin{abstract}
Every organization needs to attract, recruit and hold the best talent in today's competitive environment to survive in the marketplace. The organizations can perform at their best level by utilizing all capabilities of their employees that is possible through employees' retention. The purpose of this study was to examine the extent to which market orientation assists in achieving organization's outstanding financial performance by retaining its core employees. A total of 300 self-administrative questionnaires were distributed and only 266 employees gave feedback. Out of 266, response of 18 employees was found incomplete. The data was analyzed with the help of SPSS software. The results demonstrated that market orientation has a significant role in employee retention as well as outstanding organizational financial performance. The outcomes of this study will help organizations understand the importance of market orientation in achieving superior organizational financial performance and in retaining key employees.
\end{abstract}

Keywords: Market orientation, Competitive Edge, Organizational Performance, Retention 


\section{Introduction}

The strategic staffing has become an important issue because the ability to attract and keep highly talented employees is very essential for future survival (Anitha and Begum, 2016; Obeidat and Yousef, 2012; Messersmith, 2013; Karikari et al., 2015; Ettorre, 1997; Whitner, 2001). Firms always strive to retain the high quality of human resources in order to achieve the sustainable competitive advantage (Jackson, Schuler and Jiang, 2014; Wright, Dunford, and Snell, 2001; Becker and Gerhart 1996; Wright, McMahan and McWilliams 1994; Ferris et al 1999, Pfeffer 1994) in the modern social era of globalization where employees prefer to work with their employer of choice. It is predominantly mandatory for any organization to fulfill the needs of its employees. By doing so, the organization can also acquire competitive advantage by attracting and retaining talented employees in the long run. The effective strategic human resource practices are crucial to attain the competitive advantage in an organization (Haladay et al., 2015). Thus, HR plays a strategic role in creating competitive advantage (Haladay et al., 2015; Albulescu and Dascalu 2013; Choo, et al., 2010).

The market orientation (MO) is a key theoretical foundation for firms to the focus on the customers as well as employees that consists of intelligence gathering, dissemination and then a firm's management's subsequent tactics to implement the new market knowledge (Kohli and Jaworski 1990). The concept of market orientation lies at the heart of marketing theory (Levitt, 1960). According to the marketing concept, an organization's purpose is to determine the needs and wants of its customers (in this case the organization's employees) and to satisfy those needs more effectively and efficiently than the competition (Slater and Narver, 1998). Market oriented organizations aim to satisfy their customers/employees by organizing and coordinating their activities and efforts around the needs of the customers and employees (Levitt, 1960). In essence, a market oriented approach focuses primarily on improving the customerprovider relationship and, it is reflected in an organization's culture, shared values, and beliefs about focusing first on the customer's interests (Deshpande and Farley, 1999) as well as on employees' interest. Initial efforts by Kohli and Jaworski (1990) and Narver and Slater (1990) began a concentrated effort in the marketing field to better measure and understand the market orientation phenomenon (Tokarczyk et al., 2007). MO has been examined in terms of both behavioral as well as cultural perspectives. Kohli and Jaworski (1990) described MO as being associated with three behavioral components, namely, intelligence generation, intelligence dissemination, and responsiveness. Narver and Slater (1990) on the other hand, conceptualized MO as consisting of three cultural dimensions including, customer orientation, competitive orientation, and inter-functional coordination. The dominant view is that market orientation is positively related to performance (Jaworski and Kohli, 1993 ; Slater and Narver, 1994).

A number of studies are concentrated regarding the impact of a market orientation on various measures of firm performance, since the importance and awareness of market orientation has increased, researchers have attempted to better discern the complex relationships between market orientation and firm performance (Tokarczyk et al., 2007). For the purpose of this study, we utilized market orientation theory (MO) as a foundational setting which explains how organizations adapt to their internal customer environment i.e. the employees. In this study we refer customers to internal customers of an organization which are employees. By understanding their needs and by managing them in an appropriate way as compared to rival firms, any organization can easily achieve its superior financial performance and can retain employees in the long-term within organization. However, there is a dearth of research utilizing 
MO in past research with respect to employee retention, yet we argue from that theory that the internal customer i.e. the employee has the greatest impact on firm's financial performance. Employees have the ability to switch to another firm; they are now more than ever concerned about the environment; MO suggests that by focusing on the needs and demands of the current and future employees, any firm can differentiate itself from its competitors and will gain more economic benefits.

Employees switch over from one organization to another only when they cannot get satisfaction from their employer (Saari and Judge, 2004). The organizations need to consider different motivational factors to satisfy their employees. The organizations have to meet all expectations of their employees to retain them for long run. Else, if they fail to do so, their competitors might lose their talented employees. By and large, in terms of compensation and other benefits, employees of one organization compare themselves with employees of other organizations. When employees from any organization become conscious that their organization is not paying them well or not fulfilling all their desired needs relative to other organizations that pay very well and meet all expectations of their employees, then they may quit their jobs. This may in turn results in high turnover cost, loss of talented employees as well as loss of competitive advantage.

Thus, it is essential for the organizations to implement their best practices relative to their competitors in the market for employee retention. Market orientation plays a pivotal role for organizations to analyse the best practices of their competitors in understanding the needs of employees. Only by offering good and attractive benefits, the organizations can sustain their competitive advantage by keeping their core employees for a maximum period of time. Due to market orientation the organizations perform better in the marketplace than their competitors.

The one of the major challenges facing by organizations is to retain talented employees for a maximum period of time and also to gain outstanding organizational financial performance to sustain competitive advantage.

Nowadays the organizations are facing the issue of human resources because of the war of talent due to scarce opportunities for the employment. According to Lyon and Marler (2011), attraction and retention of the appropriate employees are a burning issue therefore organizations are striving hard to get the skilful and knowledgeable employees. Organizations have realized that superior organizational financial performance and retention of talented employees are essential for their survival. The good human resource management practices become ineffective if they are implemented without analysis of the employee's current and future needs as well as without the analysis of best practices of their competitors in the market place.

This paper will help organizations in Bangladesh to understand the importance of market orientation with respect to employee's need and their competitor's best practices for achieving outstanding organizational financial performance and retaining key employees in the long run. Then by analysing employee's need and best practices of their rivals, the organizations can go beyond the expectations of employees in fulfilling their needs and can retain them for a maximum period of time. Thus, the employee retention will result into employee loyalty and better organizational performance. And will enable organizations to sustain their competitive advantage through utilizing capabilities of their key employees. 
The research questions of this study are as follows:

1. Does market orientation help to retain talented employees and in achieving outstanding organizational financial performance?

2. Does market orientation help more to retain employees or in achieving superior organizational financial performance?

1. The objective of this study is to investigate the extent to which market orientation helps in retaining employees and to get superior organizational financial performance.

2. To determine whether a market orientation is more helpful in employee retention or organizational financial performance.

This paper will help organizations in Bangladesh to understand the importance of market orientation with respect to employee's need and their competitor's best practices for achieving outstanding organizational performance and retaining key employees in the long run. Then by analysing employee's need and best practices of their rivals, the organizations can go beyond the expectations of employees in fulfilling their needs and can retain them for a maximum period of time. Thus, the employee retention will result into employee loyalty and better organizational performance. And will enable organizations to sustain their competitive advantage through utilizing capabilities of their key employees.

\section{Literature Review}

\subsection{Employee Retention}

Due to globalization and emerging employment opportunities, organizations are at greater risk of losing capable human resources to other organizations. The keyword in terms of human resource management is "retention". Retention is methodical efforts of organizations with the endeavour of keeping and holding its employees for a extreme period of time. According to many researches on retention, the retention management is strategic and coherent process that begins with the inspection of the reasons that employees join an organization (Kehoe and Wright, 2013; Davies 2001; Fitz-enz 1990). Retention is given more importance in today's competitive world to get a competitive advantage. In addition to the general definition of the word, i.e. "keeping, holding, maintaining, continuation, and preventing from leaving", this word takes on a new meaning in business administration. It means "securing employees in a company". Thus every organization strives to make effective retention policy to provide a secure working environment to its employees. Therefore, a good retention strategy usually starts from hiring. After hiring the employees, the organizations have to build and foster working environment in order to strengthen the employment relationship as a basis for employee retention. Studies have revealed that retention is derived by several key factors that are needed to be managed effectively; organizational culture and structure, recruitment strategy, pay and benefits philosophy, employee support program and career development systems (Anitha \& Begum, 2016; Fitz-enz 1990). Career development plans, typical rewards and incentives can be a powerful retention tool and should be effectively addressed in corporate retention policies. Studies have revealed that HRM practices in training, compensation, reward, typical employee benefits can lead to reduced turnover and absenteeism, better quality work, improved financial performance and increased retention (Anitha \& Begum, 2016; Schlechter et al., 2015; Arthur 1994; Delaney and Huselid 1996; Snell and Dean 1992; Solomon 1992; Snell and youndt 1995; MacDuffie 
1995; Yamamoto.H 2011). Apart from financial incentives, many other sources also contribute to employee retention that include recognition of employees achievement, encouraging innovation, work life balance, communication process within organizations, organization's culture, constituent attachments, flexible work arrangements, Job satisfaction, organizational commitment, organizational justice, organizational prestige, promotion, job security and designation (Vidal-Salazar et al., 2016; Yamamoto,

2011; Hausknecht at el., 2009; Kavitha, Geetha and Arunachalam, 2011; Jins, Joy P and Radhakrishnan, 2012).

\subsection{The Concept of Organizational Financial Performance:}

The organizational performance consists of actual organizational output measured against its desired goals and objectives. According to Richard et al (2009), the organizational performance consists of three specific areas of organizational outcomes: (a) financial performance (profits, return on assets, etc); (b) product market performance (sales, etc); and (c) shareholder return (economic value added, etc). While, Cascio (2006) referred that with the degree of achievement of the goals is organizational performance. However, diverse potential organizational performance measures were considered relative to the competition from multiple organizational perspectives, including quality, productivity, profitability, customer service, market share, and return on equity (Khandwalla, 1977; Som, 2008; Kundu \& Mor, 2016). Other researchers used this term as measurements of transactional efficiency and input and output efficiency (Stannack, 1996). Barney (1991) considered organizational performance as a controversial issue between organizational researchers. Organizational performance means to define problem as well as present its solution (Hefferman and Flood 2000). Daft (2000) stated that the organizational performance is the organization's ability to accomplish its goals effectively and efficiently by utilizing its all possible resources. Similarly according to Richardo (2001), achieving organizational goals and objectives is known as organizational performance. Richardo (2001) suggested that return on equity determines organizations success and for which establishment of good employee's performance management system is very essential.

\subsection{Market Orientation}

Although an extensive number of previous researchers have conducted with regard to the relationship between market orientation and performance in companies (Mokoena \& Dhurup, 2017; Ionescu 2015; Hussain, Shah \& Akhtar 2016; Dawes, 2000; Shoham et al., 2005; Kirca et al., 2005). Many studies support the fact that implementation of market orientation in any organization will lead to superior business performance. The positive relationship between market orientation and performance of three subsequent meta-analyses on market orientation has been represented as an example of evidence (Cano et al., 2004; Kirca et al., 2005; Shoham et al., 2005). These results have received further confirmation in a meta-analysis undertaken by Grinstein (2008). For increasing business performance, market oriented corporate culture should be grappled along with the efforts to enhance market-oriented activities (Qu, 2009). Whereas Narver and Slater (1990) stated that a strong market orientation will enhance the effort to offer superior value to the buyers which will lead towards competitive advantage as well as better profitability. Positive customer responses result from market orientation of organizations. Such responses can be identified as customer satisfaction and customer retention where the customers are more likely to repurchase a product or service when they feel satisfaction by buying them (Doyle, 1995). However, 
Kohli and Jaworski (1990) also argued that market orientation be the evidence for the satisfied customers who both recommend the product to other potential customers and keep repurchasing themselves. Market oriented organizations are therefore expected to be of more benefit in contrast to those not adopting this orientation. However, Mokoena \& Dhurup (2017) pointed out that the existing literature discovered numerous barriers to the accomplishment of market orientation that are comprehensive and interconnected.

\section{Research Methodology}

Employees of three renowned cables companies established in Bangladesh were considered as population for this study. To achieve the aim of the study, the research methods consist of employee survey of cable company employees. The questionnaire was developed based on studies of literature. A five point Likert scale (1-strongly disagree to 5-strongly agree) was used to measure the responses. Two main questions were asked from the respondents. The first question was "Does the market orientation is helpful in attaining the outstanding firm's financial performance?" and the second question was "Does the market orientation is helpful in retaining the employees?" The convenience sampling procedure was applied and the questionnaire was distributed among the 300 selected employees, however only 266 employees gave feedback. Out of 266, response of 18 employees was found incomplete and not included. The remaining was analysed by using SPSS software.

\section{Data analysis, results and discussion}

Market orientation of the organization has a positive impact on organizational performance and on employee retention based on existing literature. The aim of this study was to investigate that how much organization's market orientation is helpful in retention and in achieving organizational performance. The research aims were achieved through descriptive analyses of responses using SPSS. The results are discussed as follows:

\subsection{Market Orientation Vs. Organizational Performance}

The present study was undertaken to investigate the extent to which the market orientation is helpful in achieving organizational financial performance. Superior organizational performance is usually achieved through analysis of customer needs and competitor's best strategic practices. The Table 1 and Figure 1 show the percentage of responses of the respondents. Then the respondents' responses for market orientation and organization performance were cross tabulated. The responses showed that $12.1 \%$ respondents were strongly disagreed, $20.2 \%$ were disagreed, the response of $16.9 \%$ respondents were neutral, however, $28.2 \%$ were agreed and $22.6 \%$ were strongly agreed with a given statement. Here the Chi-square value $=34.469$ reflects the relationship between two variables (Table 2). P-value $=0.005$ less than the significance level which is 0.05 , also supported for the acceptance of the hypothesis that market orientation plays a vital role in achieving outstanding organizational financial performance. 
Table 1: Frequency of Responses

\begin{tabular}{|l|l|}
\hline Rating scale & $\%$ of Responses \\
\hline SD (strongly disagree) & $12.1 \%$ \\
\hline D (disagree) & $20.2 \%$ \\
\hline NA (neutral) & $16.9 \%$ \\
\hline A (agree) & $28.2 \%$ \\
\hline SA (strongly agree) & $22.6 \%$ \\
\hline
\end{tabular}

Figure 1: Graphical Presentation of Responses

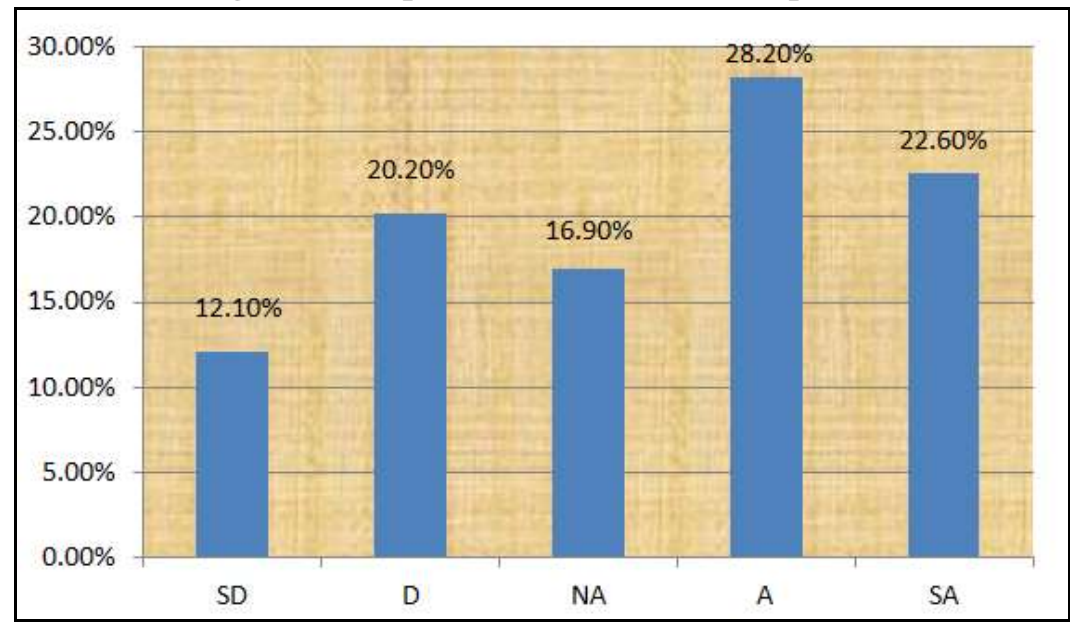

Table 2: Market Orientation* Organizational Performance Cross Tabulation

\begin{tabular}{|c|c|c|c|c|c|c|c|}
\hline & & \multicolumn{5}{|c|}{ Market Orientation } & \multirow[b]{2}{*}{ Total } \\
\hline & & $\mathrm{SD}$ & $\mathrm{D}$ & $\mathrm{NA}$ & $\mathrm{A}$ & SA & \\
\hline \multirow{5}{*}{ 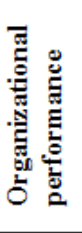 } & SD & $8(3.2)$ & $8(3.2)$ & $6(2.4)$ & $6(2.4)$ & $2(0.8)$ & $30(12.1)$ \\
\hline & D & $6(2.4)$ & $8(3.2)$ & $8(3.2)$ & $14(5.6)$ & $14(5.6)$ & $50(20.2)$ \\
\hline & $\mathrm{NA}$ & 00 & $6(2.4)$ & $10(4.1)$ & $14(5.6)$ & $12(4.8)$ & $42(16.9)$ \\
\hline & A & $10(4.1)$ & $12(4.8)$ & $10(4.1)$ & $28(11.3)$ & $10(4.1)$ & $70(28.2)$ \\
\hline & SA & $6(2.4)$ & $2(0.8)$ & $12(4.8)$ & $16(6.5)$ & $20(8.1)$ & $56(22.6)$ \\
\hline \multicolumn{2}{|c|}{ Total } & $30(12.1)$ & $36(14.5)$ & $46(18.5)$ & $78(31.5)$ & $58(23.4)$ & $248(100)$ \\
\hline
\end{tabular}

The values in brackets are the percentage; Chi-square $=34.469 ; \mathrm{p}$-value $=0.005$

$\mathrm{SD}=$ strongly disagree, $\mathrm{D}=$ disagree, $\mathrm{NA} / \mathrm{ND}=$ neutral, $\mathrm{A}=$ agree, $\mathrm{SA}=$ strongly agree 


\subsection{Market orientation Vs. Employee Retention}

It is commonly observed that market orientation plays a pivotal role in the employee retention. The Table 3 and Figure 2 show the percentage of responses of the respondents. In this section, market orientation and employee wish to stay in an organization were cross tabulated, the aim of the question regarding the market orientation is helpful on talent retention. The responses showed that $9.7 \%$ respondents were strongly Disagreed, $16.9 \%$ were disagreed, the responses of $16.9 \%$ were neutral; however, $40.3 \%$ were agreed and $16.1 \%$ were strongly agreed with the given statement. Here the Chi-square value $=29.649$ reflects the relationship. $\mathrm{P}$ value $=0.020$ was also supportive to the acceptance of the questions that the market orientation helps in employee retention (Table 4). As the P value is less than the significance level which is 0.05 . So the significance level shows that market orientation is helpful in employee retention.

Table 3: Frequency of Responses

\begin{tabular}{|l|l|}
\hline Rating scale & $\%$ of Responses \\
\hline SD (strongly disagree) & $9.70 \%$ \\
\hline D (disagree) & $16.90 \%$ \\
\hline NA (neutral) & $16.9 \%$ \\
\hline A (agree) & $40.30 \%$ \\
\hline SA (strongly agree) & $16.10 \%$ \\
\hline
\end{tabular}

Figure 2: Graphical Presentation of Responses

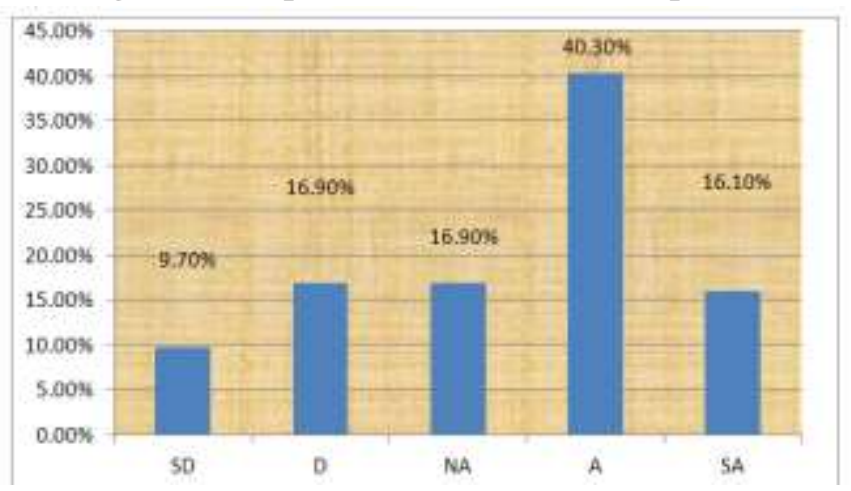

Table 4: Market Orientation* Wish Remain to Stay Retain in an Organization Cross Tabulation

\begin{tabular}{|c|c|c|c|c|c|c|}
\hline & \multicolumn{5}{|c|}{ Market Orientation } & \multirow[b]{2}{*}{ Total } \\
\hline & $\mathrm{SD}$ & D & NA & A & SA & \\
\hline \multirow{5}{*}{ 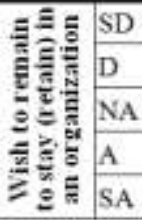 } & $2(0.8)$ & $6(2.4)$ & $6(2,4)$ & $2(0.8)$ & $8(3.2)$ & $24(9.7)$ \\
\hline & $10(4.1)$ & $6(2.4)$ & $6(2.4)$ & $14(5.6)$ & $6(2.4)$ & $42(16.9)$ \\
\hline & $8(3.2)$ & $6(2.4)$ & $6(2.4)$ & $16(6.5)$ & $6(2.4)$ & $42(16.9)$ \\
\hline & $4(1.6)$ & $12(4.8)$ & $18(7,3)$ & $38(15.3)$ & $28(11.3)$ & $100(40,3)$ \\
\hline & $6(2.4)$ & $6(2.4)$ & $10(4.1)$ & $8(3.2)$ & $10(4,1)$ & $40(16.1)$ \\
\hline Total & $30(12.1)$ & $36(14.5)$ & $46(18.5)$ & $78(31.5)$ & $58(23.4)$ & $248(100)$ \\
\hline
\end{tabular}


The values in brackets are the percentage; Chi-square $=29.649 ; \mathrm{p}$-value $=0.020$

$\mathrm{SD}=$ strongly disagree, $\mathrm{D}=$ disagree, $\mathrm{NA} / \mathrm{ND}=$ neutral, $\mathrm{A}=$ agree, $\mathrm{SA}=$ strongly agree

Thus it is clear from the above data analysis that most employees do agree that market orientation is helpful in improving or achieving organizational financial performance and also for retaining key employees. Thus, our results of the study consensus with previous studies which revealed the strong relationship between market Orientation and organization performance (Mokoena \& Dhurup, 2017; Ionescu 2015; Hussain, Shah \& Akhtar 2016; Dawes, 2000; Shoham et al., 2005; Kirca et al., 2005). From above analysis, there is strong statistical evidence of the relationship between market orientation and employee retention as well. More employees (40.3 percent) agreed that market orientation is helpful in retaining employees where as only 28.20 percent employees agreed that market orientation helps in achieving superior organizational performance. From this analysis we can say that market orientation is more helpful retaining employees than in achieving outstanding organizational financial performance.

\section{Conclusion}

After analyzing the data, it is statistically proven that there is a strong impact of market orientation $n$ employee retention as well as in attaining the organizational financial performance. This is a strong evidence regarding the importance of market orientation. Furthermore, this analysis also gives statistical evidence that the market orientation is more helpful in retention of employees than the organizational financial performance.

Thus, after the reviewing of literature and analysis of data it has been concluded that in this modern era, human resource policies become ineffective to retain the best talent in the marketplace unless they are determined according to the current and future needs of employees. Also it is not possible to retain the key employees in the long run until the organizations bench mark the best practices of their rivals in this regard. Similarly it is an important concern for the all organizations to analyze current and future needs of their customers to meet their expectations.

\section{Contribution of Paper}

The major contribution of this paper is to fill the research gap by answering the question " Is there any influence between market orientation and employee retention?" which was recommended to investigate further for future studies in the article titled as" market orientation and performance in private universities" by Zebal and Goodwin (2012). Thus this paper has provided a strong statistical evidence regarding the impact of market orientation on employee retention. Furthermore, it has added to the current knowledge of this discipline by providing statistical evidence that market orientation is more helpful in employee retention than the organizational financial performance.

\section{Limitation of Research Study}

The analysis does have some limitations which are as follow:

Firstly, since the analysis is restricted to Bangladesh perspective only and limited to only one organization, therefore single source of respondents is not enough to generalize the conclusion. Secondly, the responses of other employees working in other organizations in other countries might be different who work under different working environments. Thus, the scope of this study is very limited. Thirdly, this 
study involves merely a descriptive analysis but did not depict the relationship between the constructs through inferential analysis. In addition, since the responses were collected only from one type of respondents, thus, common method bias may be occurred that had not been detected as well as controlled in this study.

\section{Recommendations for Future Research}

Future research should comprise more longitudinal data sets with more sophisticated tests in order to disaggregate complex relationship of market orientation with organizational financial performance as well as between market orientation and employee retention. In addition, a study should be conducted regarding the relationships of above variables in different organizations. A comparison can be made by doing research on private and public organizations in determining the impact of market orientation on organizational financial performance as well as on employee retention. Additionally, the future researchers have to use the effective strategies for controlling any potential influence of common method biases especially when they use same kind of respondents to collect data.

\section{Reference}

Albulescu, S. C., \& Dascalu, O. (2013). Actual human resources tendencies in a multispeed global economy, International Journal of Business and Management, 1(6), 281-287.

Anitha, J., \& Begum, F. N. (2016). Role of Organisational Culture and Employee Commitment in Employee Retention. ASBM Journal of Management, 9(1), 17.

Arthur, J. B. (1994). Effects of human resource systems on manufacturing performance and turnover. Academy of Management Journal, 37(3), 670-687.

Becker B, Gerhart B. (1996). The impact of human resource management on organizational performance: progress and prospects. The Academy of Management Journal, 39(4), 779-801.

Barney, J.B. (1991). Firm resources and sustained competitive advantage. Journal of Management, 1 (17), 99-120.

Cascio, W. F. (2006). Managing human resources: productivity, quality of life, profits.McGraw-Hill Irwin.

Cano, C.R, Carrillat, F.A., Jaramillo, F. (2004). A meta-analysis of the relationship between market orientation and business performance: evidence from five countries. International Journal of Research in Marketing, 21(2). 179-200.

Choo, SS, Halim, H and Keng-Howe, IC (2010). The impact of globalisation on strategic human resources management: The mediating role of CEO in HR. International Journal of Business Studies, 18(1), 101.

Delaney, J. And Huseild, M. (1996). The impact of human resource management practices on perceptions of organizational performance. Academy of Management Journal, 39, 949-969.

Daft, R.L.(2000). Organization theory and design. (7th Ed.) South-Western College Publishing, Thomson Learning. U.S.A.

Dawes, J. (2000). Market orientation and company profitability: Further evidence incorporating longitudinal data. Australian Journal of Management, 25(2), 173-199.

Doyle, P. (1995). Marketing in the new millennium. European Journal of Marketing, 29(13), 23-41. 
Davies, R,(2001). How to boost staff retention. People Management. 7(8), 54-55.

Ettore, B. (1997). Making change (managing the changes made by new CEOs). Management Review. 85 (1), 13- 19.

Ferris, G. R., Hochwarter, W. A., Buckley, M. R., Harrell-Cook, G., \& Frink, D. D. (1999). Human resources management: Some new directions. Journal of Management, 25(3), 385-415.

Fitz-enz, J. (1990). Getting and keeping good employees. Personnel, 67(8), 25-28.

Grinstein, A. (2008). The relationships between market orientation and alternative strategic orientations: a meta-analysis. European Journal of Marketing, 42(1/2), 115-134.

Haladay, D., Sergio, R., Opulencia, M. J., \& Antiado, D. (2016). Moving towards strategic advantage: Transitioning from traditional human resource practices to talent management. World Review of Business Research, 6(1), 118 - 128.

Heffernan, M.M. \& Flood, P.C.(2000). An exploration of the relationship between managerial competencies organizational, characteristic and performance in an irish organization. Journal of European Industrial Training. University Press, 128-136.

Hausknecht, John P, Rodda, Julianne,Howard, Michael J(2009). Targeted employee retention: Performance-based and job-related differences in reported reasons for staying. Human Resource Management, 48(2), 269-288.

Hussain, J., Shah, F. A., \& Akhtar, C. S. (2016). Market orientation and organizational performance in small and medium sized enterprises. a conceptual approach. City University Journal, 6(01), 166180.

Jackson, S. E., Schuler, R. S., \& Jiang, K. (2014). An aspirational framework for strategic human resource management. The Academy of Management Annals, 8(1), 1-56.

Jins, Joy P.; Radhakrishnan, R.(2012). Changing jobs: Influencing factors. SCMS Journal of Indian Management. 9(1), 59-68.

Karikari, A. F., P. A. Boateng, and E. O. Ocansey (2015). The role of human resource information system in the process of manpower activities. American Journal of Industrial and Business Management, 5(06), 424.

Kavitha, S. R.; Geetha, S. R.; Arunachalam, V.(2011). An empirical study on employee retention strategies in a biscuit manufacturing company in India. Interdisciplinary Journal of Contemporary Research in Business, 3(4), 762-772.

Kehoe, R. R., \& Wright, P. M. (2013). The impact of high-performance human resource practices on employees' attitudes and behaviors. Journal of Management, 39(2), 366-391.

Kirca, A. H., Jayachandran, S., \& Bearden, W. O. (2005). Market orientation: A meta-analytic review and assessment of its antecedents and impact on performance. Journal of Marketing, 69(2), 24-41.

Kohli, A. K., \& Jaworski, B. J. (1990). Market orientation: the construct, research propositions, and managerial implications. The Journal of Marketing, 54(2), 1-18.

Kundu, S. C., \& Mor, A. (2016). Effect of diversity management on employees organisational commitment: Astudy of indian organisations. Journal of Strategic Human Resource Management, 5(1).

Lyon,D.B. and Marler, H.J.(2011). Got image? examining organizational image in web recruitment. Journal of Managerial Psychology. 26(1), 58-76. 
MacDuffie, J. P. (1995). Human resource bundles and manufacturing performance: Organizational logic and flexible production systems in the world auto industry. Industrial And Labor Relations Review, 48, 197-221.

Messersmith, J. G., J. Lee, J. P. Guthrie, and Y. Ji. (2013).Turnover at the top: Executive team departures and firm performance. Organization Science, 25 (3) 776-793.

Mokoena, B. A., \& Dhurup, M. R. (2017). Effects Of Market Orientation And Barriers To Market Orientation On University Performance: A Study Of Universities Of Technology In South Africa. The International Business \& Economics Research Journal (Online), 16(1), 17.

Narver, J. C., \& Slater, S. F. (1990). The effect of a market orientation on business profitability. The Journal of Marketing, 54(4), 20-35.

Obeidat, B. Y. (2012).The Relationship between Human Resource Information System (HRIS) Functions and Human Resource Management (HRM) functionalities. Journal of Management Research, 4 (4), 192- 211.

Pfeffer, J. (1994). Competitive edge through people: Unleashing the power of the work force. Boston: Harvard Business School Press.147-150.

Qu, R. (2009). The impact of market orientation and corporate social responsibility on firm performance: Evidence from China. Asia Pacific Journal of Marketing and Logistics, 21(4), 570-582.

Ricardo, R., \& Wade, D. (2001). Corporate performance management: how to build a better organization through measurement driven strategies alignment. Butterworth Heinemann.

Richard, P. J., Devinney, T. M., Yip, G. S., and Johnson, G. (2009). Measuring organizational performance: Towards methodological best practice. Journal of Management, 35(3), 718-804.

Schlechter, A., Thompson, N. C. and Bussin, M. (2015). Attractiveness of non-financial rewards for prospective knowledge workers. Employee Relations, 37(3), 274 - 295.

Snell, S. A., and Dean Jr, J. W. (1992). Integrated manufacturing and human resource management: A human capital perspective. Academy Of Management Journal, 467-504.

Solomon,C.M.(1992). The loyalty factor. Personnel Journal, 52, 32-37.

Snell, S. A., \& Youndt, M. A. (1995). Human resource management and firm performance: Testing a contingency model of executive controls. Journal of Management, 21(4), 711-737.

Stannack, P. (1996). Perspective on employees performance. Management Research News, 119(4/5), 3840.

Vidal-Salazar, M. D., Cordón-Pozo, E., \& de la Torre-Ruiz, J. M. (2016). Flexibility of benefit systems and sfirms' attraction and retention capacities. Employee Relations, 38(4), 487-504.

Whitener, E.M. (2001). Do high commitment human resource practices affect employee commitment? A cross-level analysis using hierarchical linear modeling. Journal of Management. 27 (5):515-64.

Wright, P. M., McMahan, G. C., \& McWilliams, A. (1994). Human resources and sustained competitive advantage: A resource-based perspective. International Journal of Human Resource Management, $5(2), 301-326$.

Yamamoto.H.( 2011). The relationship between employee benefit management and employee retention. International Journal of Human Resource Management, 22 (17), 3550-3564.

Zebal, M. A., and Goodwin, D. R. (2012). Market orientation and performance in private universities. Marketing Intelligence \& Planning, 30(3), 339-357. 